\title{
Pola Permukiman Gua-Gua Di Kaki Gunung Watangan: Suatu Hipotesis Permukiman Gua Kawasan Timur Jawa
}

\author{
Indah Asikin Nurani
}

Keywords: settlement, cave, prehistory, spatial analysis, neolithic

\section{How to Cite:}

Nurani, I. A. Pola Permukiman Gua-Gua Di Kaki Gunung Watangan: Suatu Hipotesis Permukiman Gua Kawasan Timur Jawa. Berkala Arkeologi, 15(3), 78-86. https://doi.org/10.30883/jba.v15i3.676

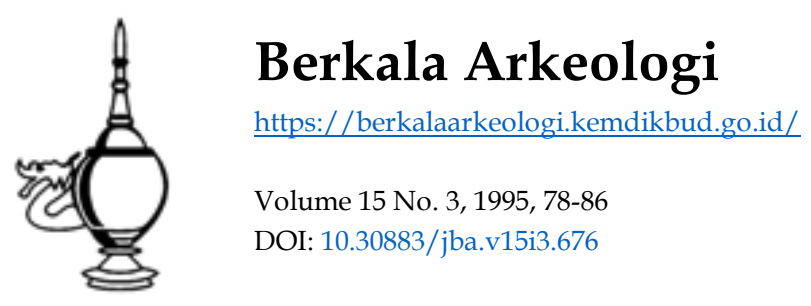

\section{(1) (2)(2)}

This work is licensed under a Creative Commons Attribution-NonCommercialShareAlike 4.0 International License. 


\title{
POLA PERMUKIMAN GUA-GUA DI KAKI GUNUNG WATANGAN: SUATU HIPOTESIS PERMUKIMAN GUA KAWASAN TIMUR JAWA
}

\author{
Indah Asikin Nurani \\ (Balai Arkeologi Yogyakarta)
}

\section{A. Latar Belakang Dan Rumusan Masalah}

Cara kehidupan dalam gua di Indonesia terjadi pada Kala Pasca Plestosen (permulaan Holosen) yang dalam terminologi prasejarah termasuk dalam periode berburu dan mengumpulkan makanan tingkat lanjut (Soejono, 1984). Pada masa ini gua (cave) ataupun ceruk (rock shelter) berfungsi sebagai tempat berlindung dan sebagai tempat melakukan aktivitas sehari-hari. Dalam mempertahankan hidupnya, manusia pada masa itu masih bergantung pada alam lingkungan sekitarnya, yang merupakan langkah adaptatif dalam mengatur dan menggunakan sumberdaya alam yang tersedia. Eksploitasi potensi ekologi oleh manusia tersebut dipengaruhi oleh tingkat teknologi dan "kecerdasan" manusia itu sendiri dalam mengolah sumber alam sekitarnya.

Sejalan dengan kecerdasan otak manusia yang makin berkembang, maka ketrampilan manusia dalam mengolah bahan-bahan alam pada kala ini makin maju pula dari masa sebelumnya. Penggunaan alat-alat dari batu untuk berbagai keperluan sehari-hari juga mengalami perkembangan bentuk dan variasinya. Alat-alat batu berupa serpih bilah merupakan jenis utama di samping alat-alat yang dibuat dari tulang, tanduk, kulit kerang, atau kayu (Soejono,1984). Dikenal, dibuat. dan dikembangkannya alat-alat tersebut sebagai salah satu bukti adaptasi manusia saat itu terhadap lingkungannya. Meskipun demikian ketergantungan mereka terhadap lingkungannya tetap berlangsung terus (Ernestene, 1973).

Di Indonesia bukti-bukti kehidupan dalam gua ini terjadi di beberapa daerah seperti Sulawesi, Nusa Tenggara Timur, Irian, Maluku, Kalimantan dan Jawa. Masing-masing kawasan permukiman gua tersebut memiliki kekhasan sendirisendiri seperti industri serpih-bilah lebih cenderung mendominasi permukiman kawasan timur Indonesia seperti Sulawesi, selain itu pada kawasan tersebut muncul tradisi melukis pada dinding gua yang berkembang dan meluas sampai ke kawasan Irian dan Maluku. Sementara itu di kawasan timur Jawa tradisi melukis pada dinding gua hingga saat ini belum pernah ditemukan. Adapun kawasan timur Jawa ini yang menjadi kekhasan tersendiri adalah industri alat tulang yang terkenal dengan sebutan Industri Alat Tulang Sampung. Penamaan industri tersebut didasarkan atas penemuan yang pertama kali yaitu di
Gua Lawa yang termasuk pada kelompok Sampung di Ponorogo.

Konsentrasi temuan alat tulang di gua-gua kawasan timur Jawa tersebut memiliki ciri-ciri yang menonjol, selain dominasi alat-alat tulang. tanduk, dan kulit kerang, terdapat juga unsur lain. Unsur lain tersebut seperti batu giling, batu pipisan, serpih bilah tanpa retus, mata panah dengan dasar melengkung, hiasan kulit kerang, dan pigmen merah. Selain itu ditemukan suatu bukti bahwa pada masa itu telah dikenal tradisi mengubur, terbukti dengan temuan kubur dalam posisi terlipat. Bukti kubur dengan posisi terlipat tersebut menarik perhatian, karena pola kehidupan manusia dalam gua ini semakin lengkap dengan temuan berupa manusia pendukungnya. Dari temuan kerangka manusia dapat diidentifikasikan bahwa pendukung gua-gua kawasan ini adalah ras Melanesoid dan beberapa unsur Australid (Heekeren, 1972).

Berangkat dari tinjauan pola permukiman gua di kawasan timur Jawa tersebut, dan masih belum tuntasnya beberapa penelitian pada guagua di kawasan ini, maka baru-baru ini Balai Arkeologi Yogyakarta telah mencoba meneliti secara tematis mengenai pola permukiman gua di kawasan ini. Sebagai tahap awal dalam penelitian dengan tema pola pemanfaatan lahan gua di kawasan timur Jawa, telah dilakukan pada salah satu komunitas gua yaitu di kaki utara G. Watangan. Pada komunitas ini terdapat beberapa gua maupun ceruk yang memiliki indikasi hunian manusia prasejarah. Hasil dari penelitian yang telah dilakukan oleh peneliti terdahulu maupun oleh Balai Arkeologi Yogyakarta dicoba dijadikan suatu model untuk mengetahui pola permukiman gua di kawasan ini dalam kaitannya dengan kaji-an arkeologi ruang. Tulisan ini dimaksudkan un-tuk mencoba mengungkap beberapa hal sehu-bungan dengan pola permukiman gua dalam ko-munitas G. Watangan. Penjabaran nantinya di-maksudkan sebagai gambaran mengenai proses budaya yang terjadi pada masa itu di kawasan ti-mur Jawa. Adapun proses budaya yang terjadi pada kawasan tersebut dikaitkan dengan konsep yang selama ini berlaku (pola permukiman, pola adaptasi, dan kajian keruangan) yang selanjutnya diterapkan pada gambaran riil mengenai proses budaya ditinjau dari beberapa aspek kehidupan masa itu. 
Untuk menjabarkan pola permukiman pada komunitas gua $G$. Watangan ini yang menjadi permasalahan adalah sebagai berikut.

1. Pola permukiman tingkat meso (komunitas) yang bagaimana yang diterapkan pada komunitas gua $G$. Watangan ?

2. Bagaimana pola perolehan makanan yang terjadi pada komunitas ini, sehubungan dengan strategi adaptasi yang dilakukan ?

3. Selain itu, penerapan dalam aspek teknologis yang mana yang dikenal dan diterapkan sehubungan dengan pembuatan perkakas seharihari untuk mengeksploitasi bahan dan potensi ekologis sekitarnya?

\section{B. Konsepsi}

Berangkat dari permasalahan dan tujuan yang hendak dicapai dalam menjelaskan dan menjabarkan pola permukiman komunitas gua $G$. Watangan ini, berikut disampaikan beberapa pendekatan dan konsep yang ada. Arkeologi permukiman dapat didefinisikan sebagai bagian dari disiplin arkeologi yang memusatkan perhatian pada persebaran okupasi dan kegiatan manusia Selain itu permukiman juga membahas menge-nai hubungan di dalam satuan-satuan ruang, de-ngan tujuan memahami sistem teknologi, sistem sosial dan sistem ideologi dari masyarakat (Mundardjito, 1990). Pengertian tersebut sesuai dengan apa yang disampaikan Parson (Parson, 1972) yaitu cara yang dilakukan oleh manusia di dalam mengatur dirinya di muka bumi tempat hidupnya. Hal itu menunjukkan bahwa suatu pola pemukiman merupakan suatu permasalahan yang begitu kompleks, karena didalamnya men-cakup beberapa aspek. Selain itu pola permuki-man mencerminkan adanya refleksi alam ling-kungan, tingkat teknologi dan macam-macam institusi yang berlaku dalam suatu komunitas gu-na mengatur alam tersebut untuk mempertahan-kan hidupnya.

Dalam mempertahankan hidupnya manu-sia pada masa prasejarah khususnya pada Kala Pasca Plestosen masih sangat bergantung pada ketersediaan potensi ekologis sekitarnya. Butzer (1982) mengungkapkan bahwa kondisi lingkungan alam senantiasa dinamis dan bukan sesuatu yang statis. Sehubungan dengan hal itu maka permukiman dapat dikatakan sebagai suatu strategi adaptasi manusia terhadap lingkungan-nya sesuai dengan tingkat kemajuan teknologi dan sistem sosial masyarakat yang bersangkutan.

Dari uraian tersebut di atas, maka dalam permukiman terdapat tiga hal yang merupakan ciri pokok suatu permukiman, yaitu 1) persebar-an; 2) hubungan-hubungan; dan 3) satuan ruang, serta asumsi-asumsi dasar yang melatarinya (Mundardjito, 1990). Persebaran peninggalan ar- keologi yang didasarkan pada bukti-bukti kegiatan manusia, selanjutnya dapat dijadikan sumber data untuk mengetahui pola pikir dan pola tindakan masyarakat masa lalu. Informasi tersebut juga diperoleh dari hubungan antar benda, sehingga perlu diperhitungkan konteks dari peninggalan arkeologis. Persebaran dan hubungan antar benda yang terjadi dalam satuan ruang sebuah bangunan akan berbeda dengan persebaran dan hubungan yang terdapat dalam satuan ruang wilayah. Satuan ruang mencerminkan gagasan dan tindakan sebuah keluarga (skala mikro), sedangkan satuan wilayah mencerminkan gagasan dan tindakan dari sekelompok keluarga atau suatu komunitas (skala meso) dan selanjutnya mencerminkan budaya kelompok komuniti atau masyarakat (makro atau tingkat kawasan) (Clarke, 1977; Mundarjito, 1990)

Kajian keruangan tingkat kawasan (makro) merupakan penjabaran mengenai arus gagasan intensitas pertukaran gagasan, kesenjangan gagasan antar komunitas atau antar masyarakat, dan lain sebagainya. Hal tersebut sehubungan dengan proses perubahan kebudayaan. Dalam penjabarannya terdapat dua faktor yang mendasari yaitu faktor eksogen dan indogen (Bugie. 1994). Faktor eksogen memandang kawasan sebagai ruang distribusi manusia dalam hal ini suatu situs yang saling berinteraksi dan bertukar gagasan (Renfrew \& Bahn, 1991). Di lain pihak faktor indogen memandang kawasan sebagai ruang adaptasi manusia (Flannery, 1972; Butzer, 1982). Artinya, perubahan kebudayaan berlangsung dalam kaitannya dengan relasi timbal-balik antara kebudayaan dengan dinamika lingkungan alam melalui pemindahan bahan, energi, dan informas: di antara masyarakatnya. Oleh karena itu. pembahasan mengenai arkeologi permukiman erat kaitannya dengan studi keruangan. Khusus untuk permukiman gua, terdapat tiga jenjang skala ruang yaitu skala mikro, meso dan makro (Indah, 1994).

\section{Komunitas Gua Pada Kawasan Timur Jawa}

Situs-situs gua di kawasan timur Jawa yang mempunyai periode hunian masa berburu dan mengumpulkan makanan tingkat lanjut yang bertepatan dengan Kala Post Plestosen di antaranya adalah Gua Lawa (Ponorogo), Gua Cantelan, Song Keplek, Song Terus (Pacitan), Gua Lawang (Bojonegoro), Gua Petpuruh (Besuki), Sodong (Jember), dan gua-gua di Tuban. Sementara itu terdapat gua yang memiliki indikasi sebagai gua yang difungsikan sebagai gua kubur-an yaitu Gua Marjan yang terletak di Jember. Be-rikut akan diuraikan mengenai beberapa hal sehubungan dengan permukiman gua kawasan ini. 


\section{Komunitas Sampung, Ponorogo}

Penelitian mengenai permukiman gua pada komunitas ini mula-mula dilakukan oleh seorang geolog, yaitu LJC van Es. Perhatiannya diawali pada banyaknya temuan tulang-tulang binatang pada salah satu gua, yaitu Gua Lawa. Temuan penyerta lainnya di gua ini sampai pada kedalaman sekitar 3,40 meter antara lain sebagai berikut (Soejono, 1984; Heekeren, 1972): serpih bilah sederhana; alat-alat tulang (terdapat dua macam sudip dan semacam belati dari tanduk); mata panah batu yang bersayap dan berpangkal konveks; hematit; perhiasan kulit kerang; kerangka manusia sikap terlipat. Dari temuan tersebut, kemudian secara sistematis penelitian dilakukan seorang arkeolog yaitu van Stein Callenfels pada tahun 1928-1931. Hasil penelitiannya menunjukkan adanya tiga lapisan budaya (Soejono, 1984; Heekeren,1972). Pada lapisan atas ditemukan perunggu-besi, tembikar modern bercampur alat-alat neolitik. Lapisan kedua ditemukan alat-alat tulang dan tanduk yang merupakan temuan ter-penting, antara lain berupa belati tanduk, lanci-pan, mata kail, dan sudip tulang (99 buah). La-pisan ketiga mengandung temuan mata panah, sumpitan, tembikar berhias pola tali, batu pi-pisan, batu giling, serpih bilah sederhana, serut kerang, dan rangka manusia terlipat.

\section{Komunitas Besuki}

Pada komunitas ini gua yang telah diteliti adaiah Gua Petpuruh, adapun kandungan temuannya berupa sudip tulang, lancipan, mata panah dari tanduk yang digosok dan berbentuk pipih, batu giling, perhiasan (cincin) dari kulit kerang mutiara yang berlobang di bagian tengahnya, serta tembikar.

\section{Komunitas Tuban}

Pada komunitas ini terdapat gugusan gua yang menyebar antara lain Gua Gedah, Gua Kandang, Gua Kecil, dan Gua Pawon. Penelitian telah dilakukan oleh Willems di daerah Semanding. Kandungan temuannya antara lain berupa alat tulang. alat kulit kerang, alat batu (mata panah bersayap), sudip tulang yang merupakan temuan sama dengan komunitas Sampung dan beberapa gua komunitas Bojonegoro.

\section{Komunitas Pacitan}

Komunitas gua Pacitan ini sebagian besar ber-ada di Kecamatan Punung dengan sebaran gua yang relatif banyak. Kandungan temuannya an-tara lain berupa alat-alat tulang, tanduk, kulit ke-rang, batu giling, batu pipisan, mata panah, dan serpih bilah.

\section{Komunitas Gua Gn. Watangan (Lojejer)}

Sebagaimana telah dijelaskan di atas, bahwa permukiman gua di kawasan timur Jawa terkenal dengan budaya industri alat tuiang beserta konteks budaya yang mendampinginya. Sesuai dengan judul tulisan ini maka berikut ini akan diuraikan mengenai kondisi riil pola permukiman yang ada dalam komunitas permukiman gua kaki utara G. Watangan. Untuk memperkuat dugaandugaan atas fenomena-fenomena yang ada pada komunitas G. Watangan (Lojejer) ini akan ditampilkan beberapa kondisi yang sama pada komunitas lain pada kawasan yang sama yaitu kawasan Timur Jawa.

Gunung Watangan terletak pada alur Pegunungan Selatan Jawa secara administratif terletak di Desa Lojejer, Kec. Wuluhan, Kab. Jember. Di daerah ini terdapat 7 situs baik berupa gua ataupun ceruk yaitu Gua Marjan dan Sodong yang secara tuntas telah diteliti oleh H.R. van Heekeren sekitar tahun 1931 sampai dengan tahun 1935, kedua gua tersebut terletak di Dusun Krajan; Gua Macan, Gua Lawa (Panas), dan Gua Gelatik di Dusun Kepel; dan Gua Macan serta Gua Lawa di Dusun Sebanen. Keadaan geografis situs gua-gua ini sama, yaitu berada pada lingkungan daerah perbukitan kapur selatan daerah sekitarnya merupakan kawasan hutan jati. Di sebelah barat dibatasi oleh beberapa bukit kapur yang diteruskan dengan dataran rendah yang bergabung dengan Pantai Puger, sedangkan bagian selatan dibatasi Gunung Watangan. Sekitar $700 \mathrm{~m}$ sebelah utara kawasan ini terdapat Sungai Ke-pel merupakan anak Sungai Bedadung yang mengalir menuju ke Samudera Indonesia. Sehingga daerah sepanjang sungai ini merupakan daerah yang subur dan oleh penduduk setempat dimanfaatkan sebagai daerah persawahan.

Situs gua dalam komunitas $G$ Watangan ini menarik perhatian sehubungan dengan data yang terkandung cenderung lengkap dan memadai dalam menginterpretasikan suatu pola permukiman skala meso sebagaimana yang diharapkan. Hal tersebut disebabkan pada pola permukiman komunitas ini data seperti sumberdaya budaya (aspek teknologi, sosial, dan ideologi), sumberdaya alam, dan pola permukimanannya cenderung lengkap. Untuk lebih jelasnya berikut ini akan diuraikan lebih lanjut.

Sebagaimana telah dijelaskan bahwa guagua komunitas G Watangan merupakan salah satu rentetan dari Pegunungan Selatan. Pegunungan Selatan sendiri merupakan sumber informasi prasejarah yang sangat lengkap dan do- 
minan dalam berbagai fase, sehingga oleh Harry Truman Simanjuntak dikategarikan sebagai "ibukota prasejarah" (Simanjuntak, 1994). Adalah tidak berlebihan bahwa komunitas permukiman daerah $G$ Watangan ini pun mengandung berbagai informasi yang memadai untuk mengungkap beberapa hal sehubungan dengan pola kehidupan masa berburu dan mengumpulkan makanan tingkat lanjut.

Komunitas permukiman gua di daerah ini sebagaimana telah dijelaskan meliputi 7 buah gua. Dua buah gua yaitu Sodong dan Marjan te-lah diteliti secara tuntas oleh van Heekeren. Berdasarkan penelitiannya van Heekeren menyimpulkan Gua Sodong (rock shelter) merupakan gua hunian, sedangkan Gua Marjan merupakan gua kuburan. Hal tersebut didasarkan pada beberapa temuan yang terkandung pada masingmasing gua.

Gua Sodong kandungan temuannya antara lain berupa serpih bilah dari beberapa bahan batu andesit, jaspis, dan kalsedon; mata panah; gurdi batu; kapak genggam (Hoabianh); alat-alat tulang berupa sudip dan lancipan; alat-alat dari kulit kerang jenis Cyrena berbentuk lengkung yang telah dikerjakan; bahan pewarna merah; gigi geraham manusia; perhiasan kulit kerang mutiara yang diberi lubang; tulang-tulang binatang sisa makan-an; dan kerangka manusia dalam posisi terlipat.

Kandungan temuan Gua Marjan sangat berbeda dengan temuan Gua Sodong yaitu ditandai dengan banyaknya temuan sisa-sisa tulang manusia di antaranya dalam keadaan utuh dan sebagian ada yang menunjukkan gejala terbakar. Rangka manusia utuh tersebut diletakkan dalam posisi terbaring, kaki terlipat dan orientasinya ke arah timur-barat dengan kepala di sebelah timur. Tengkoraknya teiah pecah dan sebagian besar mukanya telah rusak. Identifikasi rangka manusia tersebut sama dengan rangka tulang manusia dari Gua Lawa, Sampung. Ponorogo yaitu berciriciri Austramelanesoid (Heekeren,1972; Soejono, 1984).

Untuk menindak lanjuti penelitian yang terhenti berpuluh-puluh tahun lamanya tersebut, baru-baru ini Balai Arkeologi Yogyakarta yang diketuai oleh penulis sendiri mengadakan peneli-tian mengenai pola pemanfaatan lahan gua yang ada di kawasan Timur Jawa yang di dalamnya termasuk wilayah G Watangan. Berdasarkan pada tujuan penelitian berupa penjabaran mengenai pola pemanfaatan lahan gua pada kawasan Timur Jawa ini berhasil ditemukan beberapa indikasi mengenai pola permukiman yang ada dan terkandung pada komunitas gua di kakı utara G Watangan ini. Adapun gua-gua yang menjadi sasaran penelitian adalah di Gua Macan dan Gua Gelatik di Dusun Kepel. Dalam tim penelitian tersebut khusus mengenai penanganan analisis data temuan batu dilakukan oleh Harry Widianto.

Gua-gua di Dusun Kepel sebenarnya terdapat tiga buah, namun melihat kondisi ketiga gua tersebut yang memiliki indikasi gua hunian hanya dua yaitu Gua Gelatik dan Gua Macan. Sedangkan Gua Lawa atau Gua Panas (sebutan penduduk, karena kondisi di dalam gua terasa panas sekali) tidak menunjukkan indikasi sisa-sisa hunian manusia. Hal tersebut disebabkan kondis: dalam gua sangat curam dengan batu-batu karang yang tajam dan licin, selain itu di da-lam gua ini terdapat aliran sungai (sungai bawah tanah). Berdasarkan kondisi Gua Lawa tersebut maka gua ini diabaikan sebagai gua hunian dan tidak termasuk pada obyek penelitian.

Hasil dari penelitian tersebut adalah sebagai berikut (Indah, 1994a)

Gua Macan terletak di bagian paling selatan dari kaki G. Watangan. Merupakan gua yang memiliki lahan yang relatif luas dengan lapisan tanah yang tebal. Kondisi gua baik dan belum terganggu aktivitas manusia sekarang. Arah hadap gua mengarah ke Timurlaut, sehingga sirkulasi sinar matahari dalam gua terasa baik dan nyaman. Luas bentang lahan gua sekitar 17 meter (dalam gua) $X 2,25$ - 8 meter (tinggi gua) $X 7$ meter (lebar gua) Kandungan temuan gua antara lain sam-pah dapur berupa kulit kerang (molusca), alat-alat batu seperti kapak perimbas, kapak penetak, se-rut. serpih-bilah, pembelah dan alat-alat dari kulit kerang terutama berupa sudip, selain itu juga ditemukan limbah perkakas batu (tatal batu dan batu dipangkas), batu inti, dan bahan dasar. Dari temuan-temuan tersebut menunjukkan keletakan yang signifikan, dimana temuan perkakas batu cenderung banyak ditemukan pada bagian mulut gua sebelah kiri dan tengah-tengah ruangan gua. Temuan perkakas dari kulit kerang bercampuraduk dengan temuan berupa sampah dapur kerang sebagian besar berada di bagian tengah dan mulut gua bagian kanan. Dari Gua Macan ini yang menarik perhatian adalah tidak ditemu-kannya tulang-tulang binatang baik sebagai sisa makanan penghuni gua maupun sebagai bahan perkakas sehari-hari. Mengapa keadaan tersebut dapat terjadi masih memerlukan penelitian lebih lanjut.

Gua Gelatik terletak di sebeiah utara dari Gua Macan berjarak sekitar 300 meter. Kondisi Gua Gelatik (rock shelter) menarik perhatian untuk diteliti lebih lanjut. Hal tersebut disebabkan tertutupnya sebagian ruang dan dinding ceruk oleh 
endapan berupa konkresi konglomerat dengan tingkat sementasi lanjut. Konglomerat tersebut terdiri atas batu kerakal dan serpihan-serpihan batu yang tersemen oleh matriks berupa pasir kasar. Eksistensi dan genesa konglomerat tersebut belum diketahui secara jelas, karena masih belum dilakukan penelitian geologis di gua ini. Adapun temuan perkakas batu di sekitar gua ini adalah perkakas berupa kapak perimbas, kapak penetak, serpih bilah, dan serut. Temuan permukaan yang istimewa dari gua ini adalah be-rupa kapak penetak yang menunjukkan kesem-purnaan teknologi clacton dan merupakan perka-kas satusatunya dari bahan batu andhesit di si-tus Lojejer ini. Selain Gua Gelatik, perkakas batu juga ditemukan dị Sungai Curah Groncong yang terletak di antara Gua Gelatik dan Gua Macan.

Sungai Curah Groncong terletak di antara Gua Macan dan Gua Gelatik merupakan sungai yang kering pada musim kemarau dan basah pada musim penghujan. Pada saat musim kemarau dimana kondisi sungai kering, berhasil ditemukan beberapa perkakas batu dan bahan dasar perkakas batu. Pada pengamatan sepanjang 50 meter telah ditemukan beberapa perkakas berupa serpih bilah, kapak perimbas, kapak penetak, dan pahat genggam, selain itu ditemukan juga batu inti.

\section{E. Analisis Data}

\section{Sampah Dapur}

Data sampah dapur berupa sisa-sisa molusca menunjukkan bahwa penghuni Gua Macan konsumsi utamanya adalah molusca baik moluska laut maupun darat. Berdasarkan pada keletakan temuan sisa-sisa molusca yang terpolakan menarik perhatian untuk berasumsi, bahwa dalam pengolahan molusca tampak memiliki pola tersendiri. Hal tersebut didasarkan adanya konsentrasi temuan jenis molusca yang berbeda pada posisi dan tempat tersendiri dari bagian lahan gua. Pada Bagian mulut gua sebeiah kanan dan beberapa bagian di pinggiran kanan di dalam gua banyak ditemukan sisa-sisa moluska jenis gastropoda (molusca darat). Jenis gastropoda dimanfaatkan sebagai makanan dengan mematahkan ujung moluska ini dan kemudian menghisap bagian dalam (daging) molusca tersebut. Dari temuan di gua ini baik bagian ujung maupun pangkalnya bersama-sama ditemukan, sehingga tanpa ragu lagi molusca tersebut dimakan di dalam gua (Indah, 1994). Sebaliknya molusca jenis bivalve (molusca laut) banyak ditemukan di bagian tengah sampai bagian kiri dari lahan gua. Jenis ini ditemukan menggunung di mulai dari kedalaman sekitar $10 \mathrm{~cm}$ sampai pada kedalaman $120 \mathrm{~cm}$ dari permukaan tanah. Kondisi tersebut tetap berlanjut (penggalian belum sampai pada kondisi steril). Menarik untuk diperhatikan adalah kondisi molusca tersebut pada lapisan awal molusca yang ditemukan tampak hancur dan pada ke-dalaman sekitar $50 \mathrm{~cm}$ kondisi molúsca tampak utuh-utuh. Kemungkinan kondisi tersebut dise-babkan pada awalnya konsumsi molusca sangat dominan dengan persaingan pengguna tidak se-berapa. namun semakin lama konsumen molus-ca semakin banyak. Dengan kata lain kemung-kinan pada masa tertentu telah terjadi ledakan penduduk, sehingga molusca sebagai bahan makanan yang disukai dan mengandung banyak putih telur untuk pertumbuhan manusia semakin terbatas

Kondisi temuan sisa molusca ini hampir sama dengan temuan pada komunitas gua di $\mathrm{Pa}$ citan. Sisa molusca di Pacitan cukup banyak ditemukan baik berupa molusca darat maupun laut. Menarik perhatian dari temuan molusca laut pada komunitas ini adalah karena jarak antara laut dengan komunitas gua ini sekitar $15 \mathrm{~km}$. untuk penafsiran lebih lanjut tentang hal tersebut masih diperlukan penelitian lebih lanjut Lain halnya dengan temuan molusca laut pada komunitas gua di Lojejer, hal tersebut disebabkan laut ma-sih terjangkau dalam beberapa jam saja karena berjarak sekitar $3 \mathrm{~km}$. Persebaran temuan molusca laut pada komunitas Pacitan lebih menonjol pada lapisan bawah, sedangkan molusca darat lebih cenderung ditemukan pada lapisan atas (Nasruddin, 1992). Hal tersebut menarik perhatian untuk diungkap mengenai fenomena tersebut sehubungan dengan pola komunikasi antara daerah pegunungan (pedalaman) dengan komunitas di daerah pantai.

\section{Perkakas Batu dan Tulang}

Dalam teknologi litik (perkakas batu) di Indonesia memiliki proses perkembangan tersen-diri dan menyebar baik secara ruang maupun waktu. Keragaman budaya tersebut secara tek-nologis membentuk suatu garis evolusi, dari ben-tukbentuk yang kasar menuju bentuk yang lebih sempurna. Keragaman tersebut mencerminkan tingkatan-tingkatan budaya yang lengkap dan dalam terminologi prasejarah dikenal dengan $\mathrm{Pa}$ leolitik, Mesolitik, dan Neolitik. Tinggalan Paleolitik dengan unsur-unsur budaya alat masif sebagai ciri utama, menempati bentang alam terbuka atau disepanjang daerah aliran sungai, sementara itu sisa-sisa budaya Mesolitik lebih terkonsentrasi pada ceruk-ceruk atau gua-gua (bentang alam tertutup), dan sebaliknya unsur-unsur Neolitik kembali menempati bentang alam terbuka 
(Simanjuntak,1994) Jengan ciri utama perkakas yang teiah diupam.

Salah satu kegiatan yang cukup intensif pada komunitas $G$. Watangan adalah industri pembuatan alat-alat batu. Di berbagai gua di kawasan timur Jawa ini telah ditemukan antara lain pada kelompok Pacitan dan Jember. Bukti-bukti yang ada adalah dengan temuan beribu-ribu serpih menyebar baik secara horisontal maupun vertikal. Temuan tersebut menunjukkan bahwa perkakas batu dibuat di dalam gua sebagai produk perbengkeian. industri ini pada umumnya menghasilkan alat serpih dari berbagai tipe, seperti serpih bilah, serut, bor, lancipan, dan mata panah. Sebagian serpih tidak memiliki retus (penyempurnaan bentuk ataupun tajaman). Sebagian lagi memiliki retus yang terletak tidak beraturan da-lam bentuk cekungan-cekungan halus (cretouche marginale). Keberadaan industri serpih dalam konteks budaya ini menunjukkan masih kuatnya substraksi Paleolitik. Sebagaimana telah diketahui serpih bilah telah dikenal dan berkembang baik pada masa Paleolitik (Simanjuntak, 1994).

Cata berupa alat-alat dari batu pada komunitas G. Watangan merupakan hal yang menarik perhatian tersendiri. Hal iersebut disebabkan kondisi dan bahan yang tersedia di daerah in berbeda dengan komunitas gua-gua di kawasan Timur Jawa lainnya. Hal tersebut disebabkan banan batu dari komunitas $G$. Watangan yang tersedia relatif rendah kadar silikaannya. Temuan batu pada komunitas ini terdiri dari artifisial maupun non-artifisial. Temuan artifisial terdiri dari beberapa alat batu, tatal batu, batu dipangkas, dan batu inti, sedangkan yang termasuk dalam nonartifisial terdiri dari pecahan batu dan batu. Bahan dasar dari perkakas batu secara umum adalah jenis batu gamping kersikan (silicified-limstone) Pengamatan secara megaskopis terhadap materi dasar menunjukkan bahwa kualitas batu gam-ping dari situs Lojejer ini tidaklah sebaik kualitas materi dasar yang dipakai di daerah Pacitan. Hal tersebut terbuktı seperti yang ditemukan dalam lingkup alat-aiat paleolitik Kali Baksoka, komuni-tas guagua Pacitan (Nasruddin, 1992; Simanjun-tak, 1994), maupun alat-alat batu dari perbeng-kelan neolitik di Ngrijangan (Harry Widianto). Kondisi tersebut disebabkan silikaan batu di Lo-jejer belum lanjut. Selain jenis batu gamping yang lebih muda tersebut, kualitas bahan juga kurang baik karena ukuran butiran yang lebih ka-sar dan serat-serat batu yang lebih dominan. Struktur batuan seperti ini lebih mudah pecah apabila dipangkas.

Temuan unsur batu pada komunitas $G$ Watangan selain bahan dasar adalah perkakas batu seperti kapak penetak (chopping too). kapak perimbas (chopper), serpih bilah, dan serut, selain unsur penqukung perkakas yaitu limban oerupa tatal batu dan batu yang dipangkas. Berikut ini akan diuraikan mengenai unsur-unsur perkakas batu tersebut secara lebih terinci.

Kapak perimbas, unsur perkakas ini terkenal sebagai industri paleolitik yang merupakan alat-aiat batu masif yang dipangkas secara monofasial (Movius, 1948). Kapak perimbas yang ditemukan dalam konteks ini tampak adanya penerapan teknologi clacton yang dicirikan oleh pembuatan kapak perimbas terhadap serpihan-serpinan batu besar dan tebal. Temuan kapak perimbas dengan teknologi clacton tersebut pemangkasan hanya dilakukan pada bagian dorsainya saja. Selain teknologi clacton, temuan kapak perimbas ini menunjukkan adanya jumlah pangkasan yang bervariasi, dari pemangkasan tunggal memanjang hingga pemangkasan yang lebih kompleks. Pemangkasan dilakukan secara terjal dan mendekati vertikal.

Kapak penetak, kriteria terkuat dari kapak in adalah masif yang dipangkas secara bifasial (qua muka) untuk mendapatkan sisi tajamannya Temuan lainnya berupa alat batu adalah serpih bilah.

Serpih Bilah merupakan alat yang digolongkan sebagai alat non-masif yang secara teknologis menunjukkan ciri kuat tentang pelepasan dari batu intinya oleh manusia. Ciri teknologis hasil tangan manusia tersebut, seperti yang juga terlihat pada teknik clacton dari himpunan kapak perimbas, adalah eksistensi bulbus-bulbus (kerucut pukul) negatif dan dataran pukul. Dalam himpunan alat serpih di Lojejer ini sebagian besar hanya ditunjukkan adanya ciri-ciri pengerjaan tangan manusia, sedangkan ciri yang ditimbulkan oleh sifat dan jenis batuannya hampir tidak ada. hal tersebut karena rendahnya kualitas bahan batuannya. Selain itu temuan lain adalah serut.

Serut (scraper) adalah alat non-masif yang telah dipakai, yang tidak menunjukkan ciri-ciri tekno-log manusia, seperti yang ditunjukkan oleh ser-pih maupun bilah.

Kondisi perkakas batu pada komunitas $G$ Watangan ini berbeda dengan kondisi temuan perkakas batu dari komunitas gua di Pacitan. Kandungan temuan perkakas batu daiam komunitas gua di Pacitan sebagian besar merupakan serpih batu dari bahan rijang (silified limstone) Penamaan rijang adaiah penamaan lokal untuk penyebutan gamping kersikan. Selain bahan rijang juga terdapat beberapa alat lainnya dari andhesit. Berdasarkan aspek teknologisnya, yaitu 
unsur pengerjaan dan penyempurnaan (retouch), serpih dipisahkan menjadi serpih tanpa retus dan serpih dengan retus. Perbandingan keduanya kurang lebih $5: 1$. Berdasarkan temuan serpih dalam jumlah yang melimpah memperlihatkan adanya kegiatan perbengkelan di dalam gua (Nasruddin.1992). Adapun teknologi yang diterapkan pada perkakas batu kehidupan komunitas gua di Pacitan ini menunjukkan substraksi teknologi paleolitik sebagaimana yang ditemukan di gua-gua Lojejer. Perbedaannya adalah bahan batuannya lebih lanjut tingkat silikaannya, sehingga perkakas batu komunitas Pacitan ini lebih bagus dengan variasi bentuk dan tipenya, sehingga penerapan berbagai teknik yang dikenalnya dapat dilakukan tanpa terhambat oleh kondisi bahan batuannya. Tak heran apabila hasil perkakas batu dari komunitas Pacitan ini lebih bervariasi dan "canggih". Terlepas dari kualitas bahan yang tersedia pada kedua komunitas ini, tampaknya keahlian dan pengenalan teknologis keduanya sama. Bisa jadi justru pendukung komunitas $G$ Watangan memiliki ketrampilan yang lebih berkualitas dibanding komunitas Pacitan. Hal tersebut didasarkan pada hasil-hasil serpihan perkakas Lojejer lebih dapat terkendali jika dilihat dari bahannya yang relatif jelek (Indah, 1994).

Pada komunitas gua Pacitan selain ditemukan serpih bilah juga ditemukan batu pukul (percuteur) bahan baku (raw material), batu pipisan (pounding stone). Dari temuan kedua jenis pertama memperjelas kegiatan pembuatan alat di dalam gua. Adapun bahan baku merupakan bungkal-bungkal rijang yang dengan mudah ditemu-kan di sekitar gua, bentuknya tidak beraturan de-ngan beberapa bekas pangkasan terlihat di permukaannya. Dari bahan baku inilah berbagai tipe alat dihasilkan setelah melalui suatu proses pengerjaan. Kehadiran batu pukul juga memperje-las fungsinya sebagai alat pemangkas. Batu kali yang berukuran pebble ini menyimpan luka-luka pukul (stigmate de percussion) akibat benturan di kala pemangkasan.

Temuan alat mata panah merupakan salah satu produk spesifik yang dikembangkan oleh komunitas Pacitan. Terbuat dari serpih, pembentukannya dilakukan melalui pangkasan-pangkasan halus dari berbagai sisi, hingga mencapai bentuk segi tiga dengan salah satu sudutnya menjadi lancip. Bagian dasarnya dibuat meleng-kung, juga melalui pangkasan halus, sehingga menjadi ciri-ciri khas mata panah kelompok ini. Type yang sama ditemukan pada gua-gua lain di luar Jawa Timur yang merupakan pusat persebaran kelompok industri Sampung (Nasruddin, 1992).

Selain teknologi perkakas batu juga ditemukan perkakas dari kulit kerang dan perkakas tulang pada komunitas gua di Lojejer ini. Perkakas kulit kerang ditemukan beberapa di Gua Macan dan Gua Sodong, namun di Gua Macan sama sekali tidak ditemukan perkakas dari tulang dan juga tidak ditemukan tulang-tulang binatang sebagai indikasi sisa makànan penghuni gua. Indikasi perkakas tulang dan sisa binatang buruan pada pendukung komunitas gua $G$. Watangan dibuktikan dengan temuan di Gua Sodong. Hal tersebut berbeda dengan beberapa komunitas gua di kawasan timur Jawa yang sebagian besar perkakas tulang, perkakas batu dan sisa-sisa makanan baik berupa tulang binatang mamalia maupun sisa molusca ditemukan dalam satu konteks. Hal tersebut menarik perhatian untuk diungkap lebih lanjut.

Dalam komunitas gua Pacitan kegiatan pembuatan alat-alat tulang binatang ditemukan dalam jumlah yang melimpah (menonjol). Hal tersebut telah melahirkan suatu industri yang khas dari komunitas ini. Alat-alat yang dihasilkan dapat dibedakan menjadi spatula dan lancipan dengan berbagai variasi morfologis. Di luar kedua type utama ini, dihasilkan juga alat sejenis garpu dengan sisi yang bergerigi. Spatula dibuat dari tulang panjang, sisi pecahan kemudian diratakan, sementara "canal medullaire" masih terlihat dalam bentuk cekungan memanjang yang membentuk irisan cekung-cembung. Salah satu ujungnya dikerjakan lebih lanjut untuk membentuk tajaman melengkung (Nasruddin,1992; Simanjuntak, 1994). Sejauh ini melihat temuan perkakas tulang dengan sisa-sisa binatang buruan memiliki kondisi waktu yang berbeda. Hal tersebut tampak jelas pada kondisi tulang yang dipergunakan untuk perkakas telah mengalami pemfosilan, sedanigkan tulang sisa makanan tampak lebih segar. Artinya bahan untuk perkakas tulang cenderung lebih tua dibanding tulang sisa-sisa makanan penghuni gua.

\section{F. Suatu Hipotes is}

Berdasarkan uraian di atas, maka dapatlah ditarik suatu hipotesis yang didasarkan pada beberapa fenomena yang ada pada komunitas gua G. Watangan. Hipotesis ini diharapkan dapat dijadikan suatu model mengenai kondisi secara universal permukiman gua kawasan timur Jawa. Adapun beberapa hipotesis tersebut adalah sebagai berikut.

1. Pengolahan makanan molusca pada penghuni gua memiliki pola tersendiri. Molusca darat akan dimakan pàda tempat yang berbeda dengan molusca laut sehubungan dengan pemanfaatan suatu lahan gua. Frekuensi mengkonsumsi molusca juga berbeda. Hal tersebut disebabkan pada lajur komunikasi yang terj- 
angkau antara daerah pedalaman dengan daerah pantai. Selain itu konsumsi molusca juga dipengaruhi kondisi populasi penduduk dan kondisi lingkungan alam sekitarnya. Kedua kondisi tersebut sebagai strategi adaptatif manusia dalam mempertahankan hidupnya dan mengolah bahan dan potensi ekologis yang ada di alam sekitarnya.

2. Aspek teknologis pada perkakas batu dan tulang pada penghuni gua memiliki proses tersendiri pada masing-masing komunitas gua. Fenomena ini tampak jelas pada komunitas gua $G$. Watangan yang memiliki kekhasan tersendiri berupa temuan perkakas batu baik alat masif maupun non masif. Hal tersebut berbeda dengan kondisi pada temuan perkakas batu komunitas gua yang lain. Alat-alat batu pada komunitas gua Pacitan lebih didominasi tipe alat non-masif, sementara itu alat masif lebih cenderung ditemukan pada bentang alam yang terbuka dan di sepanjang aliran sungai. Perkakas batu pada kedua komunitas tersebut secara teknologis masih cenderung tampak substraksi paleolitik. Sementara itu temuan perkakas tulang pada komunitas $\mathrm{G}$. Watangan menempati sebuah gua tersendiri. Sedangkan pada komunitas gua Pacitan ditemukan bersama-sama dalam masing-masing gua.

3. Pola permukiman skala meso (komunitas) G. Watangan menunjukkan fenomena yang menarik. Hal tersebut berkaitan dengan satuan ruang pada masing-masing gua. Terbukti pada kandungan temuan masing-masing gua mencerminkan fungsi dan karakter masing-masing gua yang memiliki signifikan tersendiri. Gua Sodong dengan kandungan temuan yang menonjol berupa industri alat tulang Sampung dengan beberapa konteks yang mendampinginya. Gua Marjan lebih cenderung pada karakter gua yang difungsikan sebagai kuburan. Gua Macan lebih cenderung dimanfaatkan se-bagai sampah dapur selain juga dimanfaatkan sebagai perbengkelan disaat-saat tertentu. Sedangkan Gua Gelatik lebih menonjol pada kandungan temuan berupa perkakas batu atau dengan kata lain sebagai gua yang difungsikan sebagai perbengkelan. Selain itu yang sangat menarik adalah ditemukannya tambang dari bahan dasar perkakas batu yang tersedia melimpah di Sungai Curah Groncong dan bungkal-bungkal batu gamping di lingkungan sekitar gua. Fenomena ini menarik perhatian adanya suatu asumsi, bahwa masing-masing gua memiliki fungsi tersendiri sehubungan dengan kebutuhan dalam satu komunitas
Demikianlah beberapa fenomena yang ada pada komunitas gua di Lojejer untuk selanjutnya dapat dijadikan patokan pada permukiman gua kawasan timur Jawa. Tentunya sebagai konsekuensi dalam penelitian yang lebih luas dan menyeluruh di kawasan ini.

\section{KEPUSTAKAAN}

Butzer, 1982, Archaeology As Human Ecology Cambridge:Cambridge University Press

Clarke, David L.,1977, Spatial Information In Archaeology, in Spatial Archaeology, London: Academic Press., pp. 1-32.

Flannery, Kent V.,1972, Archaeological System Theory And Early Mesoamerica, In Mark P.Leone (ed.), Contempory Archaeology. Southern Illinios University.

Green, L. Ernestene, 1973, Populatoan, In Search Of Man,ed., Ernestene L. Green, Boston: Little,Brown and Company, pp. 339-340

Heekeren,H.R. van., 1972, Stone Age Of Indonesian, VKI, The Hague: Martinus Nijhoff

Indah Asikin Nurani, 1994, Tata Ruang Gua Pada Permukiman Gua Di Indonesia, Jejak-jejak Budaya, Yogyakarta:API Rayon II. hIm.23-33

1994a, Laporan Hasil Penelitian Arkeologi Pola Pemanfaatan Lahan Gua Di Jawa Timur Tahap If Yogyakarta:Balai Arkeologi.

Kusumohartono,Bugie M.H., 1994,Proses Perubahan Kebudayaan Dan Kajian Kawasan Dalam Arkeologi, EHPA. Palembang:Bala: Arkeologi, belum diterbitkan

Movius, Hallam Jr, 1948, The Lower Paleolithic Cultures Of Southern And Eastern Asia. Transactions Of The American Philosophi-cal Society, Philadelphia:The American Phi-losophical Society.

Mundardjito,1990, Metode Penelitian Arkeologi, Monumen Lerribaran Sastra Seri Penerbitan IImiah No. 11, Edisi Khusus,Depok: FS UI., him. 19-31. 
Nasruddin,1992, Laporan Penelitian Prasejarah Pegunungan Seribu, Jakarta:Pusat Penelitian Arkeologi Nasional.

Parson,J.R., 1972, Archaeological Settlement Patterns, In Annual Review of Anthropology, Vol. I., pp. 127-150.

Renfrew,Colin , and Paul Bahn,1991, Archaeology, Theories Methods And Practice, Thames and Hudson, Ltd.
Simanjuntak,Harry Truman,1994,Kehidupan Prasejarah Di Pegunungan Seribu, Makalah dipresentasikan dalam Ceramah IImiah Pengembangan Budaya Pegunungan Seribu. Pacitan: 29 Januari 1994.

Soejono,R.P.(ed).1984, Sejarah Nasional Indonesia I, Jakarta: Balai Pustaka 